\title{
CEO INVOLVEMENT IN SELECTING CAE, INTERNAL AUDIT COMPETENCY AND INDEPENDENCE, AND FINANCIAL REPORTING QUALITY
}

\author{
Abdulaziz ALZEBAN ${ }^{*}$ \\ Business Department, Community College, King Abdulaziz University, \\ Jeddah, Saudi Arabia
}

Received 07 January 2018; accepted 01 October 2018

\begin{abstract}
The purpose of this study is to explore the argument that Chief Executive Officer (CEO) involvement in the appointment of the Chief Auditing Executive (CAE) is detrimental to efforts to achieve good financial reporting quality (FRQ). The study is original in that to date, this precise link has not been investigated. Data are obtained via survey and annual reports relating to 307 UK companies listed on the London Stock Exchange, and the working capital and discretionary accruals are used as proxies for financial reporting quality. The findings support the contention that the benefits to FRQ of an independent and competent internal audit function are not realized when there is $\mathrm{CEO}$ involvement in the appointment of the CAE, since management is able to override IA controls. Indeed, high FRQ is only evident when the CEO is not involved in the appointment. The results are found to be robust after using two different methods of estimation, and carry the implication regulators concerned with FRQ and quality of internal audit function that the CEO should not be party to the appointment of the CAE since this will depress FRQ.
\end{abstract}

Keywords: internal audit, financial reporting quality, CEO, internal audit competency, internal audit independence, chief audit executive, audit committee.

JEL Classification: G34, M41, M42.

\section{Introduction}

The influence of internal audit (IA) competency and independence and financial reporting quality (FRQ) has been confirmed by several researchers (see for example, Abbott, Daugherty, Parker, \& Peters, 2016; Prawitt, Smith, \& Wood, 2009). Consequently, it would seem to be imperative for IA to be endowed with such independence and competence. With this in mind, the purpose of this study is to explore the issue of Chief Executive Officer (CEO) involvement in approving and appointment of the Chief Audit Executive (CAE), particularly addressing whether such involvement operates to lessen internal audit quality (IAQ), consequently FRQ.

${ }^{\star}$ Corresponding author. E-mail: aalthebyan@kau.edu.sa 
Scholars have reported the general quality of IA in monitoring financial reporting (e.g., Abbott et al., 2016; Prawitt et al., 2009), but have simultaneously documented that in securing such effectiveness, both auditor competence and independence are required (Abbott et al., 2016). Evidence is also available to support a positive association between the competences (in particular those demonstrated via professional certification) possessed by IA staff, and the FRQ of a company (Prawitt et al., 2009). That said, it is widely appreciated that whilst independence may indeed be apparent, this may be at a superficial level only, and that in reality the IA is subject to manipulation by general management. Such manipulation can arise in the selection process for the CAE. Specifically, in the case where the CEO is involved, appointment decisions can be made that determine whether or not the CAE can function independently, and not fall foul of coercive efforts to operate in the interests of management rather than shareholders. These ideas are not new, it being emphasized by the various standard-setting bodies that the appointment of the CAE should receive the approval of the Audit Committee (AC), since if properly constituted, the AC is a more appropriate body to do this. Indeed, as noted by several researchers (e.g., Abbott, Parker, \& Peters, 2010; Barua, Rama, \& Sharma, 2010; Stewart \& Kent, 2006; Goodwin, 2003), AC characteristics wield a significant influence upon on IA, and by extension, this happens through ensuring the skill and orientation of the CAE. It is, therefore, suggested in this paper that CEO involvement in the appointment of the CAE is an interference that reduces the independence enjoyed by IA.

An internal audit function (IAF) that is endowed with independence is known to produce better FRQ than one that does not operate without the involvement of general management. This fact is seen in research demonstrating the relationship between the quality of the IA and FRQ (e.g., Christ, Masli, Sharp, \& Wood, 2015; Prawitt et al., 2009), and in investigations focused on the involvement of the AC (rather than the CEO) in the matter of CAE appointment and dismissal CAE (e.g., Alzeban \& Sawan, 2015; Christopher, Sarens, \& Leung, 2009). Different variables have been used to arrive at such conclusions, but to date, no study has explored the very specific link between CEO involvement in the appointment of the CAE and the resultant FRQ. Believing the independence secured by removing the CEO from this appointment process to be a direct antecedent of improved FRQ, the current study explores that relationship using the variables of IA independence and CEO involvement in appointing the CAE, and IA competency and CEO involvement. FRQ as the overall indication of the quality of IA, is employed to establish whether or not the independence of the CAE is reduced when the decision regarding his/her appointment is in the hands of the CEO.

The paper starts with a review of the overall association between IA independence and FRQ, and competency and FRQ. This review is informed by the work of other researchers in the field (e.g., Christ et al., 2015; Prawitt et al., 2009), who concur that a strong relationship exists between the two variables of IA independence and competence, and the eventual quality of financial reporting. It then considers the issue of whether the importance of these two variables in securing FRQ is diminished when the appointment process in respect of the CAE is controlled by the CEO. The expectation is that such involvement of the CEO will reduce the effectiveness to be gained by IA independence, and IA competence. Particularly in respect of competence, the suggestion is that the CAE may be appointed on criteria other 
than his/her own expertise, and an inexpert CAE is not in a position to give professional guidance and support to other staff.

A regression model is used to test the hypotheses regarding CEO involvement in the appointment of the CAE, and particularly whether such involvement operates to impair IA independence and reduce its competency. The data used to do this are obtained from survey targeting CAEs and annual reports relating to 307 UK listed companies. Two proxies are used for FRQ, these being: change in working capital, and discretionary accruals. The results are robust and consistent for the alternative proxies. In addition a two-stage least-squares (2SLS) model is also employed to ensure the potential for endogeneity concerns is mitigated, and thereby to diminish any threat to validity. The results of the initial 2SLS remain unchanged.

The findings of the study will make a welcome contribution to the literature pertaining to several dimensions of IA activity, in particular, the CAE selection process, and FRQ. Earlier studies are complemented by this one as it demonstrates that the independency and competence of the CAE is diluted if not eradicated, when there is CEO involvement in the appointment process. Consequently, the resulting effect on the independence and competence of IA as a function, occasioned by more control over it by the CEO rather than the CAE, is highlighted in the study. Regulators concerned with FRQ and the need to institute reforms in corporate governance to improve this, will find the study's outcomes of interest, since they emphasize that the power a company allows its CEO to wield is an important antecedent of the overall quality of the IAF, irrespective of whether the IA characteristics generally are conducive to good FRQ.

After this Introduction, the paper moves to Section 1 which presents the associated literature and formulates the hypotheses. This is followed by Section 2 in which the research methodology is detailed, and by Section 3 which presents the results. A summary and discussion of the implications of the results, together with an indication of the limitations of the study and pointers for further research, appear in the conclusions section.

\section{Background and hypothesis development}

The independence and competence of the IAF is widely acknowledged to be essential in securing good corporate governance, part of which is the provision of good FRQ. Such recognition is enshrined in the internal audit standards issued by the Institute of Internal Auditors [IIA] (2017) which emphasize both the necessity for IA to enjoy independence from general management, and for the CAE to report to an organizational level that facilitates the fulfilment of IA obligations. This implies that IA reports to the AC, and not to general management, to avoid any interference. The IIA's standards (2017) are clear in explaining IA 'independence' as the ability of IA to perform its responsibilities in an unbiased way. Furthermore, those responsibilities are recognized by these standards as requiring IAs to be in possession of all the knowledge, skills, and other competencies associated with their achievement (IIA, 2017).

However, whether appropriately qualified IA staff are appointed is conditional upon the support of the hierarchical structure governing the IA department. In an ideal situation, this would require a suitably qualified CAE appointed him/herself by a suitably constituted AC. 
In this respect the IIA (2017) is clear in its recommendation that the AC be involved in approving all decisions concerned with the appointment and dismissal of the CAE.

This results from the absolute need for the IA to enjoy independence in its operation, and in this matter, it is believed by various scholars that the appointment of the CAE must be free of all prejudice that potentially could be wielded by senior management. Such freedom is considered important as a guarantee of impartiality on the part of IAs, and also as a means of liberating IAs from any fear of repercussions that they believe may be brought to bear on them by general management in the event that they (IAs) report on poor managerial behavior (Bailey, 2007). Indeed, there is evidence from Zain, Subramaniam, and Stewart (2006) that when the appointment and removal of the CAE is a matter for the AC and not general management, IAs demonstrate increased confidence in going about their tasks, and in particular those touching on sensitive issues. From this it can be understood that enhanced IA empowerment flows from AC involvement in the major decisions regarding the choice of CAE, and with this greater level of IA empowerment comes an equally greater likelihood that its recommendations will be implemented.

Reporting on the antecedents of FRQ, Abbott et al. (2016) and Prawitt et al. (2009) identify the likelihood that an independent and competent CAE is likely to increase the FRQ, and Mazza and Azzali (2015) and Lin, Pizzini, Vargus, and Bardhan (2011) identify that internal control weaknesses are also likely to be discovered before the financial statements are issued, thereby allowing for their correction. Moreover, Mazza and Azzali (2015) and Lin et al. (2011) also find that an independent and competent IAF is likely to require enhanced internal controls, and thus, to make a strong contribution to the control environment generally. These ideas echo the work of earlier researchers who find improvements in IA effectiveness and FRQ when the reporting line is to a totally independent and expert AC (e.g., Abbott, Parker, Peters, \& Raghunandan, 2003; Klein, 2002; Raghunandan, Read, \& Rama, 2001; Carcello \& Neal, 2000; Deli \& Gillan, 2000). In fact, more recent work by Abbott et al. (2016) documents the absolute need for IA independence and competence if IA is be effective in its financial reporting; and Prawitt et al. (2009), focusing on competence in particular, find a positive correlation between the professional certification of IAs, the size of the IAF, and the resultant FRQ.

However, in respect of IA independence, true independence is both apparent and real, and unfortunately the reality is often not the same as what is apparent to the observer. Specifically, it can be seen in some cultures that prohibitions do not exist against nepotism or favoritism, the result being that the CEO may appoint personal friends, business contacts or even other members of the senior management to the position of CAE. Whilst frowned upon in Western societies, in many other societies characterized by collectivism rather than individualism, such behavior is expected and loyalty to the extended family is indeed encouraged. That said, as highlighted by several scholars (see for example, Alzeban, 2015; Alzeban \& Gwilliam, 2014; Haniffa \& Hudaib, 2007), these tribal and friendship relations are powerful and have the strong potential to interfere with the effective monitoring of audit practice. In this matter, Al-Twaijry, Brierley, and Gwilliam (2002) offer concrete evidence of the damaging effect of this phenomenon, highlighting that in Saudi Arabia the intrinsic emphasis on personal connections, and the nature of society and economic enterprise which 
are characterised by hierarchy and power distance, cause problems for auditors in the fulfilment of their responsibilities since interventions are often made which detract from honest financial reporting.

Given the evidence to date, it is suggested in this study that CEO involvement in the appointment of the CAE results in lower levels of independence and competence within the IAF, and by extension an IAF with less independence and competence is unable to produce the same high quality of financial reporting that more independent and competent counterparts can. In particular, the following two hypotheses are formulated:

Hypothesis 1: When the CEO is involved in the appointment of the CAE, the influence of IA competence on FRQ is less than when the CEO is not involved in this appointment.

Hypothesis 2: When the CEO is involved in the appointment of the CAE, the influence of IA independence on FRQ is less than when the CEO is not involved in this appointment.

\section{Research methodology}

\subsection{Data}

In order to test these hypotheses, data was gathered from Datastream for the UK listed companies, with the exclusion of financial firms as they are governed by different regulatory bodies (Abbott et al., 2016; Prawitt et al., 2009; Francis \& Yu, 2009; Maijoor \& Vanstraelen, 2006). Consequently, the sample did not include companies from the financial sector, nor those with missing values. A final sample of 307 companies was achieved, representing 11 industries.

In addition, the annual reports of these companies covering the period 2014-2016, secured from either Datastream or the FAME database, were used as sources of information relating to financial statements, and in particular to the sections on corporate governance. This strategy was adopted in recognition of the connections establish in previous studies between the quality of IA and AC, and between the AC and FRQ. In this respect, the focus was on the characteristics of both the AC and the board of directors. Essentially, these characteristics relate to the independence of the board of directors, the size of the board, and the independence enjoyed by the AC (as an indication of the level of communication and overall involvement of the board and the AC in improving FRQ, and in supporting the IAF as well). Additionally, information to members of the AC, as presented in the annual reports, was consulted with the intention of identifying the amount of financial and professional expertise and experience of members. Such biographical information was also useful in providing details of AC members, taken to suggest the ability of the committee to support the IAF, and to enhance FRQ. The FRQ for each of the responding companies was calculated by using financial statements data items collected via the DataStream, and FAME databases. In terms of IA, the survey targeting CAEs in the company sample already mentioned was the data source in respect of the IA. Survey aims to obtain data related to the objectives of the study, such as respondent's background, academic qualification, professional qualification, work experience, IA's size, training, IA reporting line, performance evaluation, and appointment of CAE. 


\subsection{Measures}

\subsubsection{Financial reporting quality}

In order to test the two hypotheses it is first necessary to show what influence is anticipated to occur on FRQ by IA independence, and IA competence without the complication of the CEO involvement variable.

As a means of estimating the FRQ, the accrual quality (ACCRQ) model formulated by Dechow and Dichev (2002) is adopted. There has been wide acceptance of the Dechow and Dichev (2002) model as one that is effective for analyzing ACCRQ, not least because as noted by Doyle, Ge, and McVay (2007), it has the ability to capture biased discretionary accruals as well as unintentionally poorly estimated accruals. Consequently, the intentions of management in measuring such accruals are disregarded, and a concentration on the precision of accounting information is facilitated. The IAF has the potential to substantially influence FRQ, through its routine monitoring of management's actions, and capacity to detect choices made from self-interest, thus presenting the opportunity for the achievement of higher $A C$ CRQ is achievable (Prawitt et al., 2009). This measure is, therefore, used as a proxy for FRQ.

The focus in this model is on the relationship between the working capital accruals of the current period, and cash flows from operation from different periods. This approach allows accrual quality (ACCRQ) to be considered as the degree to which it can be compared with previous and current cash flows, and predicted for the future.

$$
\Delta W C_{t}=\beta_{0}+\beta_{1} C F_{t-1}+\beta_{2} C F_{t}+\beta_{3} C F_{t+1}+\varepsilon_{t},
$$

where: $\Delta W C_{t}-\Delta$ working capital in year $t$; this include $\Delta$ accounts receivable, $\Delta$ inventory, (-) $\Delta$ accounts payable, $\Delta$ tax payable, $(+) \Delta$ other assetsl; $C F_{t-1}-$ is operating cash flows in year $t-1 ; C F_{t}$ - is operating cash flows in year $t ; C F_{t+1}-$ is operating cash flows in year $t+1$.

Within the model of Dechow and Dichev (2002), the standard deviation of residuals is used as a company-level measure of accruals and earnings quality, in which a high match between accruals and cash flows is signified by a low standard deviation, implying both high quality accruals and earnings.

McNichols (2002), however, suggested an improvement to the model by including two variables - change in current sales, and level of $P P E$ - from the original model advanced by Jones (1991). Such improvement was argued to support both models and yield a stronger measure of $A C C R Q$. In fact, this proposal did add greater explanatory power to each of the models, and is expressed as follows:

$$
\Delta W C_{t}=\beta_{0}+\beta_{1} C F_{t-1}+\beta_{2} C F_{t}+\beta_{3} C F_{t+1}+\beta_{4} \Delta S A L E S_{t}+\beta_{5} P P E_{t}+\varepsilon_{t},
$$

where: $\triangle S A L E S_{t}$ - sales in year $t(-)$ sales in year $t-1 ; P P E_{t}$ - property, plant and equipment of a company in year $t$.

As mentioned earlier, regression is first run to test the association between IA independence and competency and accrual quality (ACCRQ) as a proxy for FRQ, and following previous studies other control variables are included which have a potential to impact $A C C R Q$, and the following regression model is used: 


$$
\begin{gathered}
A C C R Q=\beta_{0}+\beta_{1} \text { IAC }+\beta_{2} \text { IAIN }+\beta_{3} \text { ACIN }+\beta_{4} A C E X+\beta_{5} \text { BOINDEP }+ \\
\beta_{6} B O S I Z E+\beta_{7} \text { COAGE }+\beta_{8} C F+\beta_{9} \text { SAGROWTH }+\beta_{10} \text { BIGFOUR }+ \\
\beta_{11} L E V E R+\beta_{12} \text { ROA }+\beta_{13} \text { COSIZE }+\beta_{14} \text { LOSS }+\varepsilon .
\end{gathered}
$$

\subsubsection{Test variables}

Adopting the methodology of studies already reported (e.g., Prawitt et al., 2009), this study takes the following indicators as proxies to measure IA independence: (1) CAE reporting line (REPORT), A score " 1 " if the CAE is reporting directly to AC, else " 0 "; and (2) score " 1 " if the AC approves the CAE performance evaluation (EVAL), and else " 0 ". With regard to the IA competence, again as in reported studies (e.g., Pizzini, Lin, \& Ziegenfuss, 2015; Prawitt et al., 2009) this is established by the following variables: experience, certification, and training. In respect of these three proxies, experience is taken as the average number of years of IA experience, certification relates the certifications held coded " 1 " if at least one certification such as CIA and CPA is possessed, else " 0 ", and training is annual hours training. The Institute of Internal Auditors (IIA) requires a minimum of 40 hours training continuous profession education (CPE) per a year. Training is indicator coded " 1 " if 40 (and more) hours training are taken annually, and " 0 " if less than 40 hours are taken annually.

An indicator variable is incorporated within the model (Equation 3) to measure the involvement of the CEO in approving the appointment of the CAE. This variable (CEO) is equal to " 1 " where there is CEO involvement, and " 0 " otherwise. It is considered that there is CEO involvement in cases where there is a definite indication that the CEO participates in the nomination process, and such participation is determined if the company has a nominating committee and the $\mathrm{CEO}$ is a member of it, or if the firm does not have a nominating committee but states that there is an involvement from management in the CAE appointment procedures.

If neither of these two conditions are met, it is taken that the CEO is not involved. Also where there is a clear indication that the nominating committee is composed entirely of independent non-executive directors, and those members appear to be independent, then it is assumed that the CEO is not involved. However, few of the participating companies have a completely independent nominating committee, thereby precluding the direct testing of the influence of such a committee.

The UK Corporate Governance Code (Financial Reporting Council [FRC], 2016) stipulates that the procedure relating to board appointments should be led by a nomination committee which should make recommendations to the board, and that this nomination committee should be independent, comprised largely of non-executive directors. However, the Code does not require this nomination committee to be in sole charge of the CAE appointment. Nonetheless, this study assumes that the nomination committee might be involved in appointing CAE, and if this is the case, and all of its members are independent, then there is no involvement of the CEO in the CAE appointment.

It should be noted that ambiguities can arise when classifying companies in this respect, since a company may not have a nomination committee and yet also make no statement that management is involved. In such case it must be accepted that in practice there may well 
be managerial involvement, and consequently, the company concerned could be misclassified as one that does not involve its CEO in the CAE appointment. Likewise, a nomination committee exists but not be totally comprised of independent members, leading to the supposition that the CEO is indeed involved in the CAE appointment, but the actuality of this is undisclosed and unobservable. In both of these scenarios it is not possible to distinguish a company that has been misclassified from one that is properly classified, therefore, companies in these situations are excluded from the sample, and this must be noted as a shortcoming in the ability to measure the CEO variable. It must also be noted that the involvement of the CEO may result in less negative outcomes if the CAE was appointed prior to the current CEO's tenure, and hence, companies in this situation were also excluded from the sample.

\subsubsection{Control variables}

In respect of $A C C R Q$, it is acknowledged in other research that a number of other control variables are influential (P. Kent, R. Kent, Routledge, \& Stewart, 2016; Gomariz \& Ballesta, 2014; Dhaliwal, Naiker, \& Navissi, 2010; Peasnell, Pope, \& Young, 2005; Dechow \& Dichev, 2002; Dechow, Sloan, \& Sweeney, 1996). The included control variables are: age of the company (COAGE), cash flow from operation $(C F)$ to control for the company growth and also sales growth (SAGROWTH), Big 4 (BIGFOUR) if the company is audited by Big 4 , leverage (LEVER) which is measured as total liabilities divided by total assets, return on assets (ROA) which is net income divided by assets, company size (COSIZE) measured as natural log of total assets, and loss (LOSS) measured as if the company reported a loss in the prior year. Table 1 shows the definition of the variables.

In attempting to capture whether all of the AC members are indeed independent, ACIN is included as an indicator variable taken code of " 1 " if all members are independent, else " 0 ". AC expertise $(A C E X)$ is included that is equal to " 1 " if the AC has at least one accounting or auditing expertise, and " 0 " otherwise. Furthermore, two proxies are used for board of directors characteristics, these include: the independence of board of directors (BOINDEP) which is measured as the percentage of outside directors on the board; and size of board of directors (BOSIZE) equals to the number of members on the board (Castro, Galán, \& Casanueva, 2016; Kang \& Kim, 2012).

Table 1. Variables definitions

\begin{tabular}{|l|l|}
\hline \multicolumn{1}{|c|}{ Variables } & \multicolumn{1}{c|}{ Definitions } \\
\hline ACCRQ & $\begin{array}{l}\text { Change in working capital is used as the measurement of accruals quality (AC- } \\
\text { CRQ) - McNichols' model (2002). }\end{array}$ \\
\hline CEO & $\begin{array}{l}\text { CEO involvement in approving the appointment of CAE which is equal to "1" } \\
\text { where there is CEO involvement, and "0" otherwise. }\end{array}$ \\
\hline IAC & $\begin{array}{l}\text { IA competence. Three measurements are used as proxies for IA competence, these } \\
\text { are: } \\
\text { EXPER, average number of years of IA experience. } \\
\text { CERTIFICATION, "1" if at least one certification such as CIA and CPA is pos- } \\
\text { sessed, else "0"; and } \\
\text { TRAIN, is indicator coded "1" if 40 (and more) hours training are taken annually, } \\
\text { and "0" if less than 40 hours are taken annually. }\end{array}$ \\
\hline
\end{tabular}


End of Table 1

\begin{tabular}{|l|l|}
\hline \multicolumn{1}{|c|}{ Variables } & \\
\hline IAIN & $\begin{array}{l}\text { IA independence is measured by the following indicators: } \\
\text { REPORT "1" if IA primarily reports to AC, else "0"; } \\
E V A L \text { "1" if the AC approves the CAE performance evaluation, and else "0". }\end{array}$ \\
\hline ACIN & AC independence measured as "1" if all members are independent, else "0". \\
\hline ACEX & $\begin{array}{l}\text { AC expertise which is equal to "1" if the AC has at least one accounting or audit- } \\
\text { ing expertise, and "0" otherwise. }\end{array}$ \\
\hline BOINDEP & The proportion of outside directors on the board. \\
\hline BOSIZE & Number of members on the board. \\
\hline COAGE & Company's age, number of years since year of operation. \\
\hline CF & Cash flow from operations. \\
\hline SAGROWTH & Growth rate in sales over prior year. \\
\hline BIGFOUR & Coded "1" if the auditor is one of the Big 4, "0" else. \\
\hline LEVER & Total liabilities divided by total assets. \\
\hline ROA & Return on assets (net income/assets). \\
\hline COSIZE & Company's size: natural log of total assets. \\
\hline LOSS & "1" if a loss in the prior year, else "0". \\
\hline
\end{tabular}

\section{Results}

The descriptive statistics are shown in Table 2, from which it seen that approximately one third (0.32) of all companies in the survey, reported that the CEO was indeed involved in both the nomination of the CAE, and in the subsequent approval of the appointment. Hence, in these cases, the CEO is either a member of the nomination committee or involved in some other managerial activity concerned with the CAE appointment. In the majority of the sample, where non-involvement of the CEO is reported, this occurs either because the nomination is made by a body that is $100 \%$ independent, or suggested that there is no involvement by CEO or management. The assumption is made in this study, that those companies reporting greater IA independence and competency, will also report greater FRQ, and that companies operating with independent nomination committees (or no $\mathrm{CEO} / \mathrm{managerial}$ involvement) likewise benefit from greater IA independence and competency, and consequently better FRQ. The logical conclusion to draw is that IA independence and competence, and FRQ are diminished when CEO involvement is apparent in the CAE appointment.

Table 2. Descriptive statistics

\begin{tabular}{|l|c|c|c|c|c|}
\hline \multicolumn{1}{|c|}{ Variable } & Max. & Min. & Mean & Median & S.D. \\
\hline ACCRQ & 0.303 & 0.00 & 0.083 & 0.058 & 0.068 \\
\hline CEO & 1.00 & 0.00 & 0.32 & 0.00 & 0.62 \\
\hline EXPER & 27.00 & 9.00 & 10.40 & 10.00 & 2.46 \\
\hline CERTIFICATION & 1.00 & 0.00 & 0.85 & 1.00 & 0.22 \\
\hline TRAIN & 1.00 & 0.00 & 0.60 & 1.00 & 0.51 \\
\hline
\end{tabular}


End of Table 2

\begin{tabular}{|l|c|c|c|c|c|}
\hline \multicolumn{1}{|c|}{ Variable } & Max. & Min. & Mean & Median & S.D. \\
\hline REPORT & 1.00 & 0.00 & 0.80 & 1.00 & 0.69 \\
\hline EVAL & 1.00 & 0.00 & 0.70 & 1.00 & 0.62 \\
\hline ACIN & 1.00 & 0.00 & 0.85 & 1.00 & 0.35 \\
\hline ACEX & 1.00 & 0.00 & 0.45 & 0.00 & 0.23 \\
\hline BOINDEP & 0.82 & 0.20 & 0.60 & 0.50 & 0.17 \\
\hline BOSIZE & 19.00 & 5.00 & 9.15 & 9.00 & 2.11 \\
\hline COAGE & 51.00 & 14.00 & 20.50 & 18.00 & 12.75 \\
\hline CF & 1.44 & -0.24 & 0.13 & 0.11 & 0.13 \\
\hline SAGROWTH & 5.12 & -0.78 & 0.14 & 0.12 & 0.38 \\
\hline BIGFOUR & 1.00 & 0.00 & 0.91 & 1.00 & 0.21 \\
\hline LEVER & 1.42 & 0.04 & 0.62 & 0.61 & 0.23 \\
\hline ROA & 112.40 & -54.42 & 9.72 & 7.45 & 10.13 \\
\hline COSIZE & 11.15 & 7.25 & 9.10 & 8.90 & 0.69 \\
\hline LOSS & 1.00 & 0.00 & 0.14 & 0.00 & 0.33 \\
\hline
\end{tabular}

Notes: ACCRQ is accruals quality; CEO is chief executive officer involvement in the appointment of the chief auditing executive (CAE); IA competency is measured by three elements: experience (EXPER), professional qualifications (CERTIFICATION), and training (TRAIN); IAIN is IA independence measured by IA reporting line to AC (REPORT), and whether CAE performance evaluation (EVAL) is approved by AC; $A C I N$ is $\mathrm{AC}$ independence; $A C E X$ is expertise of $\mathrm{AC}$ members; BOINDEP is independence of board of directors; BOSIZE is size of board of directors; COAGE is age of the company; CF cash flow from operations; SAGROWTH is sales growth; BIGFOUR is Big 4 auditors; LEVER is leverage; $R O A$ is return on assets; COSIZE company size; LOSS is a measure of whether a company reported a loss in the prior year.

The association between independence and competency of IA and FRQ is examined initially, without including the CEO involvement variable, and Table 3 presents the results of the regression in this respect, from which it is seen that significant negative relationships exist between IA independence and ACCRQ $(P<0.01)$, and between IA competence and ACCRQ $(P<0.01)$.

Table 3. Regression results of model $3-A C C R Q$

\begin{tabular}{|l|c|c|c|c|}
\hline \multicolumn{1}{|c|}{ Item } & Coefficient & $\mathrm{t}$ & $\mathrm{P}$ & $\mathrm{VIF}$ \\
\hline IAC & -0.369 & -3.92 & $0.000^{* *}$ & 1.396 \\
\hline IAIN & -0.407 & -4.11 & $0.000^{* *}$ & 1.791 \\
\hline ACIN & -0.387 & -4.03 & $0.000^{* *}$ & 1.416 \\
\hline ACEX & -0.322 & -3.86 & $0.002^{* *}$ & 1.512 \\
\hline BOINDEP & -0.298 & -3.14 & $0.009^{* *}$ & 1.637 \\
\hline BOSIZE & -0.193 & -2.80 & $0.016^{*}$ & 1.685 \\
\hline COAGE & -0.064 & -1.87 & 0.062 & 1.177 \\
\hline CF & 0.188 & 2.72 & $0.020^{*}$ & 1.466 \\
\hline
\end{tabular}


End of Table 3

\begin{tabular}{|l|c|c|c|c|}
\hline \multicolumn{1}{|c|}{ Item } & Coefficient & $\mathrm{t}$ & $\mathrm{P}$ & $\mathrm{VIF}$ \\
\hline SAGROWTH & 0.174 & 2.37 & $0.042^{*}$ & 1.354 \\
\hline BIGFOUR & -0.218 & -2.85 & $0.012^{\star}$ & 1.529 \\
\hline LEVER & 0.181 & 2.53 & $0.033^{*}$ & 1.687 \\
\hline ROA & 0.159 & 2.29 & $0.048^{*}$ & 1.538 \\
\hline COSIZE & -0.307 & -3.28 & $0.007^{* *}$ & 1.713 \\
\hline LOSS & 0.075 & 1.91 & 0.054 & 1.225 \\
\hline N: 307 & & & & \\
\hline Adj. $\mathrm{R}^{2}: 0.57$ & & & & \\
\hline P $<0.001$ & & & & \\
\hline
\end{tabular}

Notes: ${ }^{*}$ Significant at $0.05 ;{ }^{*}$ significant at $0.01 ;$ VIF is variance inflation factor for testing multicollinearity; IAC is IA competency measured by three indicators: experience (EXPER), professional qualifications (CERTIFICATION), and training (TRAIN); IAIN is IA independence measured by IA reporting line to $\mathrm{AC}$, and whether $\mathrm{CAE}$ performance evaluation is approved by AC; ACIN is AC independence taking code of " 1 " if members are all independence, " 0 " else; ACEX is AC expertise taking code of " 1 " if there is at least one member with experience in accounting or auditing, "0" otherwise; BOINDEP is percentage of outside directors on the board; BOSIZE is number of members on the board; COAGE is age of the company; $C F$ cash flow from operations; $S A G R O W T H$ is growth rate in sales over prior year; BIGFOUR taking code of " 1 " if auditor is one of the Big 4, " 0 " else; LEVER liabilities divided by assets; $R O A$ return on assets equal to net income/assets; COSIZE natural log of total assets; LOSS taking code of " 1 " if a loss in the prior year, else " 0 ".

Subsequently, an analysis is made of whether CEO involvement in the CAE appointment diminishes the advantages of IA independence and competence. The results from this regression (Equation 4) are reported in Table 4.

$$
\begin{gathered}
A C C R Q=\beta_{0}+\beta_{1} C E O+\beta_{2} I A C+\beta_{3} C E O \times I A C+\beta_{4} I A I N+\beta_{5} C E O \times I A I N+ \\
\beta_{6} A C I N+\beta_{7} A C E X+\beta_{8} \text { BOINDEP }+\beta_{9} \text { BOSIZE }+\beta_{10} C O A G E+\beta_{11} C F+ \\
\beta_{12} \text { SAGROWTH }+\beta_{13} \text { BIGFOUR }+\beta_{14} L E V E R+\beta_{15} R O A+ \\
\beta_{16} \text { COSIZE }+\beta_{17} \text { LOSS }+\varepsilon .
\end{gathered}
$$

The association between IAC (IA competence) which measures the link between IAC and ACCRQ (accrual quality) when there is no CEO involvement in the appointment of the CAE, is seen to be significantly negative $(P<0.01)$. It therefore, differs when the CEO participates in the activity, as revealed that there is no significance interaction between IAC and CEO involvement $(P>0.05)$. Hence, $\mathrm{H} 1$ is supported since the results show that the involvement of the CEO in the CAE appointment can not only diminish, but also potentially eradicate the quality and competence of IA, and consequently, the FRQ when measured by ACCRQ.

Likewise, Table 4 reports the results of testing the association between IAIN (IA independence) and ACCRQ when there is no CEO involvement in the appointment of the CAE, and the regression shows this to be significantly negative $(P<0.01)$. However, the combined between IAIN and CEO involvement shows no significance $(P>0.05)$ - suggesting no significant association between IAIN and ACCRQ when there is involvement from the CEO. 
Hence, $\mathrm{H} 2$ is supported, meaning that $\mathrm{CEO}$ involvement in the CAE appointment eradicates IA independence, IA quality, and subsequently FRQ, as measured by ACCRQ.

Table 4. Regression results of model $4-A C C R Q$

\begin{tabular}{|c|c|c|c|c|}
\hline Item & Coefficient & $\mathrm{t}$ & $\mathrm{P}$ & VIF \\
\hline $\mathrm{CEO}$ & 0.046 & 1.57 & 0.073 & 1.729 \\
\hline IAC & -0.386 & -4.01 & $0.000^{\star *}$ & 1.405 \\
\hline $\mathrm{CEO}^{*} \mathrm{IAC}$ & 0.033 & 1.25 & 0.102 & 1.478 \\
\hline IAIN & -0.422 & -4.29 & $0.000^{\star *}$ & 1.788 \\
\hline $\mathrm{CEO}^{*}$ IAIN & 0.028 & 1.14 & 0.163 & 1.709 \\
\hline ACIN & -0.381 & -3.97 & $0.003^{\star *}$ & 1.413 \\
\hline ACEX & -0.302 & -3.18 & $0.008^{\star *}$ & 1.518 \\
\hline BOINDEP & -0.316 & -3.27 & $0.006^{\star *}$ & 1.642 \\
\hline BOSIZE & -0.190 & -2.85 & $0.018^{*}$ & 1.679 \\
\hline COAGE & -0.057 & -1.73 & 0.071 & 1.170 \\
\hline $\mathrm{CF}$ & 0.186 & 2.78 & $0.021^{\star}$ & 1.458 \\
\hline SAGROWTH & 0.177 & 2.46 & $0.039^{*}$ & 1.294 \\
\hline BIGFOUR & -0.225 & -2.90 & $0.011^{*}$ & 1.478 \\
\hline LEVER & 0.183 & 2.60 & $0.030^{*}$ & 1.690 \\
\hline ROA & 0.164 & 2.37 & $0.043^{*}$ & 1.541 \\
\hline COSIZE & -0.337 & -3.32 & $0.005^{\star *}$ & 1.717 \\
\hline LOSS & 0.069 & 1.81 & 0.062 & 1.231 \\
\hline \multicolumn{5}{|l|}{ N: 307} \\
\hline \multicolumn{5}{|l|}{ Adj. $R^{2}: 0.61$} \\
\hline $\mathrm{P}<0.001$ & & & & \\
\hline
\end{tabular}

Notes: ${ }^{\star}$ Significant at $0.05 ;{ }^{* *}$ significant at 0.01 ; VIF is variance inflation factor for testing multicollinearity; $\mathrm{CEO}$ is CEO involvement in approving the appointment of CAE taking code of " 1 " where there is CEO involvement, and "0" otherwise; IAC is IA competency measured by three indicators: experience (EXPER), professional qualifications (CERTIFICATION), and training (TRAIN); CEO ${ }^{\star} I A C$ is joint test measuring the association between IAC and ACCRQ when there is involvement from the CEO in the appointment of CAE; IAIN is IA independence measured by IA reporting line to AC, and whether CAE performance evaluation is approved by $\mathrm{AC}$; $C E O^{\star} I A I N$ is joint test measuring the association between IAIN and ACCRQ when there is involvement from the CEO in the appointment of CAE; ACIN is AC independence taking code of " 1 " if members are all independence, " 0 " else; ACEX is AC expertise taking code of " 1 " if there is at least one member with experience in accounting or auditing, " 0 " otherwise; $B O I N D E P$ is percentage of outside directors on the board; BOSIZE is number of members on the board; $C O A G E$ is age of the company; $C F$ cash flow from operations; $S A G R O W T H$ is growth rate in sales over prior year; BIGFOUR taking code of "1" if auditor is one of the Big 4, "0" else; LEVER liabilities divided by assets; ROA return on assets equal to net income/assets; COSIZE natural log of total assets; LOSS taking code of " 1 " if the company reported a loss in the prior year, else " 0 ".

Given the expectation that the IA competence and independence are likely to be influenced by the CEO involvement in the appointment of the CAE, further tests were performed (for brevity, the results are not reported), which indicate that in companies where is no involvement of the CEO, approximately $70 \%$ of IAFs report primarily to the AC. These 
companies are more likely to have higher IA competences in terms of experience and annual training, and hence, higher FRQ. The $X^{2}$ test indicates significant differences $(P<0.01)$ between these companies and companies where s no involvement of the CEO. Further, the link between ACCRO and CEO involvement is tested when IA reports primarily to the AC and the CAE performance evaluation is approved by AC but when IA is not entirely competent, and when IA is entirely competent but not entirely independent. The unreported results indicate that these relations are not significant $(P>0.05)$, suggesting that the effects of IA competences and independence on ACCRQ are significant, and hence that there is higher FRQ when there is no involvement from the CEO.

In sum, the findings demonstrate that CEO involvement in the appointment of the CAE removes the benefits gained by IA competency and independence, and their subsequent effect on FRQ, even if the IA is competent and independent. The associations between $A C$ $C R Q$ and $I A C^{\star} C E O$ and $I A I N^{*} C E O$ are not significant $(P>0.05)$, and the significant association between IAC, IAIN and ACCRQ $(P<0.01)$ reveal that this situation only prevails where there is no CEO involvement in the CAE appointment, thereby confirming that such involvement threatens IA competency and independence. It also indicates that a competent and independent IA will not yield enhanced FRQ where there is CEO involvement in the CAE appointment. Seemingly, such involvement influences FRQ through its negative impact on the competences and independence of IA. These results confirm those obtained in other studies that find IA competences and independence to generate increased FRQ (Abbott et al., 2016; Prawitt et al., 2009), and to assist management to exert heavy control over financial reporting by lessening the shortage of internal control mechanisms (Mazza \& Azzali, 2015; Lin et al., 2011).

\subsection{Robustness test}

Two additional tests are performed to ensure consistency of the results, the first one being the use of a different proxy for FRQ, which is that featuring in Kasznik's (1999) model of discretionary accruals (DISAC) founded on the earlier work of Jones (1991). The equation is as follows:

$$
T A_{i, t}=\beta_{0}+\beta_{1} \Delta S A L E S_{i, t}+\beta_{2} P P E_{i, t}+\beta_{3} \Delta C F_{t+1}+\varepsilon_{i, t}
$$

$T A_{i, t}$ represents total accruals which is measured as $\Delta$ non-liquid current assets (-) $\Delta$ current liabilities (+) $\Delta$ the short-term bank debt (-) depreciation. $\triangle S A L E S_{i, t}$ represents $\Delta$ revenues; $P P E_{i, t}$ represents property, plant and equipment; $\Delta C F_{i, t}$ represents $\Delta$ cash flow from operations.

The following model is produced to measure the impact of $C E O$ involvement in the appointment of CAE on FRQ (measured by DISAC):

$$
\begin{gathered}
\text { DISAC }=\beta_{0}+\beta_{1} C E O+\beta_{2} \text { IAC }+\beta_{3} \text { CEO } \times \text { IAC }+\beta_{4} \text { IAIN }+\beta_{5} C E O \times I A I N+ \\
\beta_{6} A C I N+\beta_{7} A C E X+\beta_{8} \text { BOINDEP }+\beta_{9} \text { BOSIZE }+\beta_{10} C O A G E+\beta_{11} C F+ \\
\beta_{12} \text { SAGROWTH }+\beta_{13} \text { BIGFOUR }+\beta_{14} L E V E R+\beta_{15} \text { ROA }+ \\
\beta_{16} \text { COSIZE }+\beta_{17} \text { LOSS }+\varepsilon .
\end{gathered}
$$


It can be seen in Table 5 that there is significant negative association between DISAC and IAC $(P<0.01)$ when there is no CEO involvement in the appointment of the CAE, whereas there is no relation with DISAC when there is an involvement of the CEO in appointing CAE $(P>0.05)$. Similarly results show that the relation between DISAC and IAIN (IA independence) is significantly negative at $(P<0.01)$. However, there is no significant association with DISAC when involvement from the CEO $(P>0.05)$. It can be seen in Table 5 that the results are consistent with the original ones and therefore, they are robust in their analysis that involvement of the CEO in the appointment of the CAE both reduces, and in some cases, eliminates the competence and independence of $I A$, and hence has a negative knock-on effect on FRQ.

The second test to establish robustness explores the possibility of endogeneity in respect of the elements employed to construct IA quality. This test involves a two-stage least squares (2SLS) analysis adopting an instrumental variable approach (Abbott et al., 2016; Prawitt et al., 2009). Since there is no high correlation with the IA independence variables in the study, and they do not therefore influence IA competence (IAC) significantly, the main concentration is on predicting IAC in a first-stage regression. As with Abbott et al. (2016) and Prawitt et al. (2009), the aim is to use the instrumental variables that correlate with IA competence. These variables are: average IA competence score by industry, and the amount of inventory relative to assets. Subsequently, a second-stage regression is run in which the predicted IA competence value is used together with the set of dependent variables reported in Table 4, and the outcomes are almost the same.

Table 5. Regression results of model 6 - DISAC

\begin{tabular}{|c|c|c|c|c|}
\hline Item & Coefficient & $\mathrm{t}$ & $\mathrm{P}$ & VIF \\
\hline CEO & 0.059 & 1.61 & 0.081 & 1.622 \\
\hline IAC & -0.377 & -3.96 & $0.000^{* *}$ & 1.381 \\
\hline $\mathrm{CEO}^{*} \mathrm{IAC}$ & 0.042 & 1.16 & 0.112 & 1.459 \\
\hline IAIN & -0.401 & -4.15 & $0.000^{* *}$ & 1.795 \\
\hline CEO $^{\star}$ IAIN & 0.038 & 1.05 & 0.138 & 1.721 \\
\hline ACIN & -0.293 & -3.88 & $0.005^{\star *}$ & 1.436 \\
\hline ACEX & -0.276 & -3.48 & $0.007^{\star \star}$ & 1.529 \\
\hline BOINDEP & -0.255 & -2.99 & $0.009^{* *}$ & 1.661 \\
\hline BOSIZE & -0.181 & -2.71 & $0.024^{*}$ & 1.693 \\
\hline COAGE & -0.052 & -1.54 & 0.092 & 1.147 \\
\hline $\mathrm{CF}$ & -0.079 & -1.97 & 0.051 & 1.428 \\
\hline SAGROWTH & 0.151 & 2.58 & $0.034^{*}$ & 1.304 \\
\hline BIGFOUR & -0.209 & -2.86 & $0.019^{*}$ & 1.466 \\
\hline LEVER & 0.102 & 2.49 & $0.037^{\star}$ & 1.706 \\
\hline ROA & 0.097 & 2.38 & $0.041^{*}$ & 1.552 \\
\hline COSIZE & -0.318 & -3.91 & $0.001^{\star *}$ & 1.698 \\
\hline LOSS & 0.068 & 1.69 & 0.077 & 1.217 \\
\hline
\end{tabular}


End of Table 5

\begin{tabular}{|l|l|l|l|l|}
\hline \multicolumn{1}{|c|}{ Item } & Coefficient & $\mathrm{t}$ & $\mathrm{P}$ & VIF \\
\hline $\mathrm{N}: 299$ & & & & \\
\hline Adj. $\mathrm{R}^{2}: 0.52$ & & & & \\
\hline $\mathrm{P}<0.001$ & & & & \\
\hline
\end{tabular}

\section{Conclusions}

Previous studies have found IA competence and independence to be definite indications of IA quality, and therefore, that when present, these phenomena bring improvements in FRQ as measured by accrual quality. In this study, it is suggested that the advantages gained from IA competence and independence are lessened when the CAE appointment is not made independently of the CEO's involvement. To investigate this suggestion, the association between FRQ and IA competence and independence, is explored in the context of the formal participation of the CEO is the CAE appointment, and the study provides confirmation that the advantages to be gained by IA competence and independence in terms of improved FRQ, are found only when there is no involvement of the CEO in this respect. These findings indicate that management finds it possible to override IA controls when the CAE appointment has been subject to CEO intervention.

Furthermore, these findings indicate that the CAE appointment should be a matter for the AC, in keeping with the UK Corporate Governance Code, which as previously mentioned, stipulates the need for a nomination committee with a majority of independent members to spearhead this appointment. Implicitly, this recognizes the risks to FRQ which are inherent when the CEO is influential in appointing the CAE. However, the Corporate Governance Code does not required all members of the committee to be independent non-executive directors, and this leaves the way open for managerial members to be appointed. Another concern is that it is only companies trading on an exchange that are subject to these regulations, and yet another is that social connections between directors and the CEO might improve the chances of those directors becoming members of the nominating committee and themselves doing the bidding of the CEO, and losing their impartiality. These are concerns to which all companies and IAs must be alert.

In conclusion, it should be pointed out that the study as reported is subject to certain limitations, the first being in the possibility that measurement error has occurred in determining whether or not there is CEO involvement in CAE appointments within the sample population. Consequently, a more precise measure of this phenomenon is required in future studies. It would also be helpful in a future study to expand the sample to secure data from more companies with nomination committees as this would reduce the ambiguity surrounding the measure of CEO involvement. Moreover, it might be useful to integrate the findings from this study with those of other research efforts for validation purposes. These additional actions have the potential to spearhead future academic debate on the issue of managerial interference in the appointment of the CAE. 


\section{References}

Abbott, L., Daugherty, B., Parker, S., \& Peters, G. (2016). Internal audit quality and financial reporting quality: the joint importance of independence and competence. Journal of Accounting Research, 54(1), 3-40. https://doi.org/10.1111/1475-679X.12099

Abbott, L., Parker, S., \& Peters, G. (2010). Serving two masters: the association between audit committee internal audit oversight and internal audit activities. Accounting Horizons, 24(1), 1-24. https://doi.org/10.2308/acch.2010.24.1.1

Abbott, L., Parker, S., Peters, G., \& Raghunandan, K. (2003). The association between audit committee characteristics and audit fees. Auditing: A Journal of Practice \& Theory, 22(2), 17-32. https://doi.org/10.2308/aud.2003.22.2.17

Alzeban, A. (2015). The impact of culture on the quality of internal audit: an empirical study. Journal of Accounting, Auditing, \& Finance, 30(1), 57-77. https://doi.org/10.1177/0148558X14549460

Alzeban, A., \& Gwilliam, D. (2014). Factors affecting the internal audit effectiveness: a survey of the Saudi public sector. Journal of International Accounting, Auditing and Taxation, 23(2), 74-86. https://doi.org/10.1016/j.intaccaudtax.2014.06.001

Alzeban, A., \& Sawan, N. (2015). The impact of audit committee characteristics on the implementation of internal audit recommendations. Journal of International Accounting, Auditing and Taxation, 24(1), 61-71. https://doi.org/10.1016/j.intaccaudtax.2015.02.005

Al-Twaijry, A., Brierley, J., \& Gwilliam, D. (2002). An examination of the role of audit committees in the Saudi Arabian corporate sector. Corporate Governance, 10(4), 288-297. https://doi.org/10.1111/1467-8683.00293

Bailey, J. (2007). Best practices for internal auditor independence. Internal Auditing, 22(2), 34-37.

Barua, A., Rama, D., \& Sharma, V. (2010). Audit committee characteristics and investment in internal auditing. Journal of Accounting and Public Policy, 29(5), 503-513.

https://doi.org/10.1016/j.jaccpubpol.2010.09.001

Carcello, J., \& Neal, T. (2000). Audit committee composition and auditor reporting. The Accounting Review, 75(4), 453-467. https://doi.org/10.2308/accr.2000.75.4.453

Castro, I., Galán, J., \& Casanueva, C. (2016). Management of alliance portfolios and the role of the board of directors. Journal of Business Economics and Management, 17(2), 215-233. https://doi.org/10.3846/16111699.2014.958093

Christ, M., Masli, A., Sharp, N., \& Wood, D. (2015). Rotational internal audit programs and financial reporting quality: Do compensating controls help? Accounting, Organizations and Society, 44, 37-59. https://doi.org/10.1016/j.aos.2015.05.004

Christopher, J., Sarens, G., \& Leung, P. (2009). A critical analysis of the independence of the internal audit function: evidence from Australia. Accounting, Auditing \& Accountability Journal, 22(2), 200220. https://doi.org/10.1108/09513570910933942

Dechow, P., \& Dichev, I. (2002). The quality of accruals and earnings: The role of accrual estimation errors. The Accounting Review, 77(4), 35-59. https://doi.org/10.2308/accr.2002.77.s-1.35

Dechow, P., Sloan, R., \& Sweeney, A. (1996). Causes and consequences of earnings manipulation: An analysis of firms subject to enforcement actions by the SEC. Contemporary Accounting Research, 13(1), 1-36. https://doi.org/10.1111/j.1911-3846.1996.tb00489.x

Deli, D., \& Gillan, S. (2000). On the demand for independent and active audit committees. Journal of Corporate Finance, 6(4), 427-445. https://doi.org/10.1016/S0929-1199(00)00016-X

Dhaliwal, D., Naiker, V., \& Navissi, F. (2010). The association between accruals quality and the characteristics of accounting experts and mix of expertise on audit committees. Contemporary Accounting Research, 27(3), 787-827. https://doi.org/10.1111/j.1911-3846.2010.01027.x 
Doyle, J., Ge, W., \& McVay, S. (2007). Accruals quality and internal control over financial reporting. The Accounting Review, 82(5), 1141-1170. https://doi.org/10.2308/accr.2007.82.5.1141

Financial Reporting Council. (2016). The UK corporate governance code. London: FRC. Retrieved from www.frc.org.uk

Francis, J., \& Yu, M. (2009). Big 4 office size and audit quality. The Accounting Review, 84(5), 1521-1552. https://doi.org/10.2308/accr.2009.84.5.1521

Gomariz, F., \& Ballesta, J. (2014). Financial reporting quality, debt maturity and investment efficiency. Journal of Banking and Finance, 40, 494-506. https://doi.org/10.1016/j.jbankfin.2013.07.013

Goodwin, J. (2003). The relationship between the audit committee and the internal audit function: evidence from Australia and New Zealand. International Journal of Auditing, 7(3), 263-278. https://doi.org/10.1046/j.1099-1123.2003.00074.x

Haniffa, R., \& Hudaib, M. (2007). Locating audit expectations gap within a cultural context: the case of Saudi Arabia. Journal of International Accounting, Auditing and Taxation, 16(2), 179-206. https://doi.org/10.1016/j.intaccaudtax.2007.06.003

Institute of Internal Auditors. (2017). International standards for the professional practice of internal auditing. Retrieved from http://www.theiia.org

Jones, J. (1991). Earnings management during import relief investigations. Journal of Accounting Research, 29(2), 193-228. http://doi.org/10.2307/2491047

Kang, S., \& Kim, Y. (2012). Effect of corporate governance on real activity-based earnings management: evidence from Korea. Journal of Business Economics and Management, 13(1), 29-52. https://doi.org/10.3846/16111699.2011.620164

Kasznik, R. (1999). On the association between voluntary disclosure and earnings management. Journal of Accounting Research, 37(1), 57-81. http://doi.org/10.2307/2491396

Kent, P., Kent, R., Routledge, J., \& Stewart, J. (2016). Choice of governance structure and earnings quality. Accounting Research Journal, 29(4), 372-390. https://doi.org/10.1108/ARJ-06-2014-0056

Klein, A. (2002). Audit committee, board of director characteristics, and earnings management. Journal of Accounting and Economics, 33(3), 375-400. https://doi.org/10.1016/S0165-4101(02)00059-9

Lin, S., Pizzini, M., Vargus, M., \& Bardhan, I. (2011). The Role of the internal audit function in the disclosure of material weaknesses. The Accounting Review, 86(1), 287-323. https://doi.org/10.2308/accr.00000016

Maijoor, S., \& Vanstraelen, A. (2006). Earnings management within Europe: the effects of member state audit environment, audit firm quality and international capital markets. Accounting and Business Research, 36(1), 33-52. https://doi.org/10.1080/00014788.2006.9730005

Mazza, T., \& Azzali, S. (2015). Effects of internal audit quality on the severity and persistence of controls deficiencies. International Journal of Auditing, 19(3), 148-165. https://doi.org/10.1111/ijau.12044

McNichols, M. (2002). Discussion of the quality of accruals and earnings: The role of accrual estimation errors. The Accounting Review, 77(S1), 61-69. https://doi.org/10.2308/accr.2002.77.s-1.61

Peasnell, K., Pope, P., \& Young, S. (2005). Board monitoring and earnings management: do outside directors influence abnormal accruals? Journal of Business Finance and Accounting, 32(7/8), 13111346. https://doi.org/10.1111/j.0306-686X.2005.00630.x

Pizzini, M., Lin, S., \& Ziegenfuss, D. (2015). The impact of internal audit function quality and contribution on audit Delay. Auditing: A Journal of Practice \& Theory, 34(1), 25-58. https://doi.org/10.2308/ajpt-50848

Prawitt, D., Smith, J., \& Wood, D. (2009). Internal audit quality and earnings management. The Accounting Review, 84(4), 1255-1280. https://doi.org/10.2308/accr.2009.84.4.1255 
Raghunandan, K., Read, W., \& Rama, V. (2001). Audit committee composition, "Gray director", and interaction with internal auditing. Accounting Horizons, 15(2), 105-118.

https://doi.org/10.2308/acch.2001.15.2.105

Stewart, J., \& Kent, P. (2006). Relation between external audit fees, audit committee characteristics and internal audit. Accounting and Finance, 46(3), 387-404. https://doi.org/10.1111/j.1467-629X.2006.00174.x

Zain, M., Subramaniam, N., \& Stewart, J. (2006). Internal auditors' assessment of their contribution to financial statement audits: the relationship with audit committee and internal audit function characteristics. International Journal of Auditing, 18(1), 1-18.

https://doi.org/10.1111/j.1099-1123.2006.00306.x 